\title{
Realization of Various Acts on Initiation Rank: Case Study of Mad'u Speech in Dialogic Da'wah Discourse
}

\author{
Miftah Nugroho ${ }^{1}$, Hesti Widiastuti ${ }^{2}$, Bakdal Ginanjar ${ }^{3}$, Asep Yudha Wirajaya ${ }^{4}$ \\ $\left\{1{ }^{1}\right.$ miftahnugroho@staff.uns.ac.id, ${ }^{2}$ hesti w@staff.uns.ac.id, ${ }^{3}$ bakdalginanjar@staff.uns.ac.id, \\ 4asepyudha@staff.uns.ac.id\} \\ ${ }^{1234}$ Universitas Sebelas Maret
}

\begin{abstract}
Dialogic da'wah (preaching) discourse is an interaction between mad'u and dai. Interactions commonly include elements of initiation, response, and feedback. Every element in the interaction consists of various acts. This article emphasizes the description of act contained in the element of initiation. This article wants to show the difference between classroom discourse and dialogic preaching discourse on the elements of initiation. The data in this article are speech utterances when mad'u asking questions. The source of the data in this article is dialogical preaching, both organized by Islamic mass organizations and non-mass organizations in Surakarta. The method of obtaining data is listen and record method. Data analysis uses Birmingham School of Discourse Analysis theory. The results of the data analysis show that not all acts that occur in the classroom discourse are found in the dialogic preaching discourse. Even, there are acts that are not found in the classroom discourse. This arises because the acts in the initiation in the dialogic preaching discourse delivered by mad'u.
\end{abstract}

Keywords: act, mad'u, initiation, dialogic da'wah discourse

\section{Introduction}

Dialogical da'wah discourse is an interaction that is different from ordinary conversation. Conversation is "talk in which two or more participants freely alternate in speaking, which generally occurs outside specific institutional settings like religious services, law courts, classrooms and the like."[1]. Meanwhile, in the dialogic da'wah discourse, there are more than two participants involved, but the alteration of the speech is not as free as in ordinary conversation. This factor is one of the reasons why dialogical preaching is interesting to study.

In various study it is stated that an interaction has a structure. The study that examines the structure of an interaction can be divided into two, namely the analysis of conversations and the Birmingham school of discourse analysis [2];[3];[4]. Conversation analysis is an approach to study usual conversations. Meanwhile, unusual conversations or institutional interactions are examined using the Birmingham school of discourse analysis approach. In the meantime, the dialogical preaching discourse can be categorized as institutional interaction because the alteration of speech is not free as ordinary conversation. Therefore, an appropriate study to 
examine the structure of dialogical preaching is the analysis of the Birmingham school of discourse.

Birmingham school of discourse analysis initially appears to examine the interactions found in classroom discourse. According to this approach, interaction as discourse has five ranks, namely act, move, exchange, transaction, and lesson[5]. Act is the lowest rank that makes up the move. In classroom discourse, there are 21 acts namely marker, starter, check, prompt, clue, cue, bid, nomination, information, directive, acknowledge, reply, react, comment, accept, evaluate, silent stress, meta-statement, conclusion, loop, and aside. Meanwhile, various acts compose move. Move includes three types namely opening, answering, and follow up. Each move consist of different classes of act. Then, the three classes of move compose exchange. The opening move arranges the initiation, the answering moves compose the response, and the follow-up moves compose the feedback. At the exchange rank there is the IRF (initiation-response-feedback) formula. The terms emerging in this rank are teacher inform, teacher direct, teacher elicit, pupil elicit, pupil inform, and check. Furthermore exchanges combine transactions and transactions combine lesson.

As explained before that dialogic da'wah discourse can be categorized as an institutional interaction examined by the Birmingham school of discourse analysis. Therefore, dialogic da'wah discourse certainly has five ranks as classroom discourse. However, the problem is whether the five ranks of the classroom discourse also apply to the dialogic da'wah discourse. Furthermore, what is also interesting to review in depth is whether the various acts in the classroom discourse also appear in the dialogic da'wah discourse.

In addition to the above reasons, this study is also carried out because no previous studies of the Birmingham school of discourse have analyzed the da'wah. The study that has been done uses discourse analysis approach[6] which discusses aspects of grammatical and lexical cohesion. There are studies that discuss the elements of cohesion and coherence in the discourse of preaching[7]. Meanwhile, the use of Birmingham's discourse analysis is more applied in the aspects of teaching [8];[9];[10]. Based on these facts, the study of the acts that contain in the opening move at the initiation becomes relevant to be carried out.

This study only discusses the acts, especially those that combine opening moves. In classroom discourse, the opening move is usually from the teacher and the acts that combine the opening move are starter, marker, elicitation, informative, directive, check, prompt, clue, cue, bid, and nomination. Meanwhile, the response move consist of acts such as acknowledgment, reply, react, and comment. The acts that contained in feedback are accept, evaluate, and comment. Based on the description, it appears that the opening move consists of acts rather than the answer move and feedback move. As an initiation or the beginning of an interaction, acts that arise in classroom discourse are not only dominated by elicitation, but also other acts. In the meantime, the act contained in the opening or initiation move are mostly uttered by the teacher. This is of course interesting when applied to other types of discourse such as dialogic discourse. In a dialogic dialogue, interaction begins when a question and answer session is opened. During the session an interaction between mad'u and dai took the form of mad'u asking questions and dai giving responses in the form of answers. In other words, initiation is mostly done by mad'u and responses are done by dai. What is interesting to study further is whether the acts consisted in the opening and initiating moves in dialogic da'wah discourse are different from the classroom discourse. Therefore, this study intends to describe the various acts consisted in the opening and initiating moves in dialogic da'wah discourse. 


\section{Research Method}

This study is classified as a qualitative study because the resulting research procedure is in the form of descriptive data of written or oral words that come from the people and behaviors observed [11]. The data in this article are speeches when asking questions in a question and answer session. The source of the data are from dialogic da'wah organized by Islamic organizations in Surakarta such as Muhammadiyah and MTA (Qur'anic Interpretation Council) and informal organization. Meanwhile, the data was obtained by using the observation technique. The following techniques are the no-participatory observe, record, and note-taking techniques [12] [13]. In other words, observing, recording, as well as note-taking about specific things are done at the same time when mad'u and dai interactions. After the data is collected, the next steps are classify and analyze the data with the theory of Birmingham school of discourse analysis.

\section{Results And Discussion}

The results of data analysis showed that the acts consisted in initiation in dialogic da'wah discourse are eight acts, namely greeting, bid, starter, informative, clue, directive, elicitation, and marker. All of these acts do not consist simultaneously the opening moves and initiation. However, in the opening and initiation act the most important is elicitation because mad'u are given the opportunity to ask questions. The following is an example of the mad'u utterance at the opening moves and initiating consisted with various acts.(1)

\begin{tabular}{lll}
\hline Speaker & \multicolumn{1}{c}{ Utterance } & Act Class \\
\hline Mad'u: & $\begin{array}{l}\text { Yen anu Pak, menawi sok-sok nembe ngaji, ngoten nggih. Ngoten napa ya kedah } \\
\text { mandheg napa diteruske? }\end{array}$ & $\begin{array}{l}\text { Starter } \\
\text { elicitation }\end{array}$ \\
& $\begin{array}{l}\text { What if, Sir, when I am reciting the Koran, right, } \\
\text { what should I do, stop or continue? }\end{array}$ & \\
\hline
\end{tabular}

In (1) above, an opening moves and initiation starts with a starter "Yen anu Pak, menawi sok-sok nembe ngaji, ngoten nggih. What if, Sir, when I am reciting the Koran, right" After the speech, mad'u give elicitation with "Ngoten napa ya kedah mandheg napa diteruske? What should I do, stop or continue?" Thus, the opening moves and initiating in (1) are arranged with starter and elicitation.

Meanwhile, in (2) the opening moves and initiation consist of starter, informative, and elicitation.(2)

\begin{tabular}{|c|c|c|}
\hline \multirow{3}{*}{$\begin{array}{l}\text { Speaker } \\
\text { Mad'u: }\end{array}$} & Utterance & Act Class \\
\hline & $\begin{array}{l}\text { Ini berhubungan dengan sholat. Nah sehabis sholat dhuha kan ada sholat } \\
\text { rawatib dua rekaat. Terus itu kan ada yang melakukan, terus seorang datang itu } \\
\text { langsung makmum gitu. Itu gimana Ustad? }\end{array}$ & $\begin{array}{l}\text { starter } \\
\text { informative }\end{array}$ \\
\hline & $\begin{array}{l}\text { This is related to prayer. Well, after the Duha prayer there are two rakaat } \\
\text { rawatib prayer. Then there was someone who did it, and then a person came } \\
\text { straight as makmum to it. How is that, Ustad? }\end{array}$ & elicitation \\
\hline
\end{tabular}

In (2) above the opening moves and initiation moves are not directly consisting with elicitation, but are preceded by a starter through speech "Ini berhubungan dengan sholat" This relates to prayer." Next, mad'u conveyed informative through the speech "Nah sehabis sholat dhuha kan ada sholat rawatib dua rekaat. Terus itu kan ada yang melakukan, terus seorang 
datang itu langsung makmum gitu" 'Well, after the Duha prayer there are two rakaat rawatib prayer. Then there was someone who did it, and then a person came straight as makmum to it'. At the end of the opening and initiation, the mad'u is closed with elicitation through speech "Itu gimana Ustad?" 'How is that, Ustad?' Thus, the opening moves and initiation in (2) found that mad'u starting the speech by the act initiating, followed by the act of informing, and ending with the act of elicitation or questioning.

In the meantime, the opening moves and initiation in (3) below are comprise with acts that differ from (1) and (2) above.(3)

\begin{tabular}{lll}
\hline Speaker & \multicolumn{1}{c}{ Utterance } & Act Class \\
\hline Mad'u: & Tanya Ustadz, ini kalau penyembelihan qurban tidak di masjid gimana? Tidak & Bid \\
& sekitar masjid, sebab tempat saya ada itu tempat pengajian tapi bukan masjid & elicitation \\
& $\begin{array}{l}\text { I want to ask, Ustadz, what if the sacrifice of the qurban is not in the mosque? } \\
\text { informative } \\
\text { Not around the mosque, because my place is a preaching place but not a }\end{array}$ & \\
& & \\
\hline
\end{tabular}

In (3) the opening moves and initiation are comprised with bid, elicitation, and informative. Bids are delivered through a speech "Tanya Ustadz" 'I want to ask, Ustadz'. Meanwhile, elicitation is stated with "ini kalau penyembelihan qurban tidak di masjid gimana?" "what if the sacrifice of the qurban is not in the mosque'. Then the informative expressed with utterance "Tidak sekitar masjid, sebab tempat saya ada itu tempat pengajian tapi bukan masjid." "Not around the mosque, because my place is a preaching place but not a mosque.' Thus, the opening moves and initiation moves is realized by delivering the bid first. The goal is to gain dai attention to mad'u. After that, mad'u immediately states elicitation and informative. Informative delivered to strengthen the question.The opening and initiating moves in the following (4) are different from (1), (2), and (3) (4)

\begin{tabular}{lll}
\hline Speaker & \multicolumn{1}{c}{ Utterance } & Act Class \\
\hline Mad'u: & $\begin{array}{l}\text { Assalamualaikum warahmatullahi wabarakatuh. Niki terkait dengan jawaban } \\
\text { Pak Bari. Kebetulan saya ini kan juga pedagang. Jadi penghasilan tiap bulan itu }\end{array}$ & starter \\
& tidak selalu sama. Berbeda kalau dengan pegawai. Penghasilan segini berarti & \\
& jatahnya segini. Nah menurut agama, cara peng, penghitungan zakat itu & \\
& bagaimana? Di pedagang itu kan kadang ya untung, kadang ya rugi. Kadang & elicitation \\
& untung tapi masih diutang. Apakah itu juga termasuk ee harta yang wajib untuk & clue \\
& dizakatkan? & \\
& Assalamualaikum warahmatullahi wabarakatuh. This is related to Mr. Bari's & elicitation \\
& answer. I happen to be a trader too. So the income every month is not always the & \\
& same. It's different with employees, certain amount of income means certain & \\
& calculation. So according to Islam, how you calculate zakat? For the merchant, \\
& sometimes it's profitable, sometimes it's loss. Sometimes profitable but still \\
& owed. Does that also include assets that are obligatory to be zakat? & \\
\hline
\end{tabular}

The opening moves and initiation in (4) begin with a greeting "Assalamualaikum warahmatullahi wabarakatuh." Then mad'u conveyed the starter with "Niki terkait dengan jawaban Pak Bari. Kebetulan saya ini kan juga pedagang. Jadi penghasilan tiap bulan itu tidak selalu sama. Berbeda kalau dengan pegawai. Penghasilan segini berarti jatahnya segini" 'This is related to Mr. Bari's answer. I happen to be a trader too. So the income every month is not always the same. It's different with employees, certain amount of income means certain calculation.' After that, mad'u expresses elicitation through speech "Nah menurut agama, cara peng, penghitungan zakat itu bagaimana?" "According to Islam, how you calculate zakat?' To make it easier to understand, mad'u adds information by conveying clues through speech "Di pedagang itu kan kadang ya untung, kadang ya rugi. Kadang untung tapi 
masih diutang." "for the merchant, sometimes it's profitable, sometimes it's loss. Sometimes profitable but still owed.' At the end of the opening move and initiation, mad'u convey elicitation again through speech "Apakah itu juga termasuk ee harta yang wajib untuk dizakatkan?" 'Does that also include assets that are obligatory to be zakat?' Thus, the opening moves and initiation in (4) are arranged through four acts, namely greeting, starter, elicitation, and clue. Before delivering the elicitation, mad'u begins with greeting, then continues with the starter. After that, mad'u conveyed eliciatiton and clue to clarify information. In closing to the opening and incisation (4), the mad'u use elicitation again.

From (1) - (4) it appears that the acts that comprise the opening and initiation moves consist of 6 acts, namely greeting, bid, starter, informative, elicitation, and clue. However, the results of data classification and data analysis show that the acts that comprise the opening and initiation moves consist of 8 acts as summarized in the following table.

Table 1 Distribution of acts on opening and initiating moves

\begin{tabular}{llcr}
\hline & Act class & Frequency & Percentage \\
\hline Initiation/ Opening move & Greeting & 4 & $7 \%$ \\
& Bid & 4 & $7 \%$ \\
& Starter & 12 & $20 \%$ \\
& Informative & 14 & $23 \%$ \\
& Directive & 1 & $2 \%$ \\
& Elicitation & 19 & $31 \%$ \\
& Clue & 1 & $2 \%$ \\
& Marker & 6 & $10 \%$ \\
& & 61 & $100 \%$ \\
\hline
\end{tabular}

Table 1 above shows that many elicitation are delivered by mad'u because in the opening moves and initiation mad'u are able to give questions. Various starter are also expressed by mad'u because the function that act is as preliminary information before asking. Meanwhile, informative is also often found because mad'u also expresses a variety of information before asking questions. The greeting is only found a little because mad'u prefers to directly state what is being asked even though it is preceded by introductory information. Likewise, the bid is also rarely found because the dai basically has look at mad'u when giving questions. The directive is found very rarely because this act usually is uttered by dai. Therefore, directives are rarely spoken by mad'u. Clue is also rarely found because when delivering introductory mad'u have already delivered a lot of starter or informative. The table above also shows that when asking questions, mad'u does not directly give questions, but it will be preceded by introductory information. The reason is that the dai can understand the importance of the question so that the answer is easy to understand.

\section{Conclusion}

Based on the description above, it can be concluded that the acts that comprise the opening moves and initiation in dialogic da'wah discourse have similarities with the classroom discourse. The difference is that in dialogic da'wah discourse, greeting is found. In contrast, the greeting in classroom discourse is not found. Many starters are expressed by mad'u, indicating that the initial information needs to be conveyed before asking a question so that it is easy to understand the question and be able to give precise and clear answers. This article examines only the acts of opening moves and initiation. Further research regarding the 
response and feedback moves needs to be done so that understanding of the interactions in dialogic da'wah discourse becomes more comprehensive and holistic.

\section{References}

[1] S. C. Levinson, Pragmatics, First. Cambridge: cambridge university press, 1983.

[2] G. Cook, Discourse. Oxford University Press, 1989.

[3] J. Cutting, Pragmatics and discourse : a resource book for students. Routledge, 2008.

[4] D. Archer, K. Aijmer, and A. Wichmann, Pragmatics : an advanced resource book for students. Routledge, 2012.

[5] M. Coulthard, Advances in spoken discourse analysis. 2013.

[6] K. (UNS) Sadhono, "Analisis Wacana Khotbah Jumat: Pendekatan Mikrostruktural dan Makrostruktural," Surakarta, 2005.

[7] D. (UGM) Atmawati, "Wacana Dakwah Beberapa Dai/Daiyah Terkemuka di Indonesia," Gadjah Mada University Press, 2009.

[8] A. White and a M. F. Assignment, "the Application of Sinclair and Coulthard' S Irf Structure To a Classroom Lesson : Analysis and Discussion," 2003.

[9] H. Sauntson, Approaches to Gender and Spoken Classroom Discourse. London: Palgrave Macmillan UK, 2012.

[10] P. Raine, "an Application of the Sinclair and Coulthard ( 1975 ) Method of," no. March, 2017.

[11] L. J. Moeleong, Metode Penelitian Kualitatif. Bandung: Rosda, 2011.

[12] Sudaryanto, Metode dan Aneka Teknik Analisis Bahasa: Pengantar Penelitian Wahana Kebudayaan secara Linguistis. Yogyakarta: Duta Wacana Press, 1993.

[13] K. Saddhono, N. E. Wardani, and C. Ulya. "Sociopragmatic approach on discourse structure of friday prayer's sermon in java and madura island." J. of Lang and Lit, vol. 6 no. 1 pp 26-29, 2015. 